\title{
Kaposi's sarcoma and the new herpesvirus
}

The Austro-Hungarian dermatologist, Moritz Kaposi, first described Kaposi's sarcoma (KS) over 100 years ago [1] as a rare, slowly progressive tumour of elderly males with lesions mainly confined to the skin of the extremities. It later emerged that a more aggressive $\mathrm{KS}$ was endemic in central Africa. In developed countries, $\mathrm{KS}$ is now most commonly associated with HIV infection, and is characterised by widely distributed lesions, visceral as well as lymph node involvement and a rapidly progressive course. It also occurs iatrogenically in immunosuppressed individuals.

The clinical presentation of $\mathrm{KS}$ is unusual. Often, multifocal lesions arise de novo in distributions inconsistent with metastatic spread. New lesions contain multiple cell types which form slit-like vascular spaces lined by flattened endothelial cells. A cellular infiltrate of lymphocytes and plasma cells is often present. Later lesions are dominated by more uniform spindle-like cells. Several growth factors are produced by the different cell types present in KS lesions in vivo and in vitro and may be required for their growth $[2,3]$. Cultures established from $\mathrm{KS}$ tumours may induce ' $\mathrm{KS}$-like' lesions of murine origin when injected into nude mice [4], showing that some of the released growth factors can induce the development of such lesions. These observations, together with reports of regression of $\mathrm{KS}$ lesions in transplant patients after withdrawal of immunosuppressive medication, suggest that early $\mathrm{KS}$, at least, is not truly malignant.

However, the monoclonal nature of individual KS nodules [5] and the fact that 'malignant' cell lines (tetraploid karyotype, growth as human tumour in nude mice) can be established from biopsies [6] suggests the possible transformation of some cells to a malignant phenotype. The origin of $\mathrm{KS}$ spindle cells is still controversial. Vascular or lymphatic endothelium, cells from venous lymphatic junctions, fibroblasts, smooth muscle cells and dermal dendrocytes have all been proposed as possible progenitors.

The rarity of $\mathrm{KS}$ in patients with haemophilia in contrast to homosexual men with HIV infection, and its geographic distribution suggest a sexually acquired infective cause [7]. In 1994, DNA of a previously unknown herpesvirus was discovered in KS lesions, but not in unaffected tissue from the same patient [8]. The two fragments of herpes viral DNA obtained had a high degree of homology with herpesvirus saimiri, an oncogenic herpesvirus which can cause T-cell lymphomas in New World monkeys, and with Epstein-Barr virus [8]. The complete genomic sequence has recently been published [9].

Several lines of evidence suggest that this virus, currently called Kaposi, sarcoma-associated herpes virus, or human herpesvirus 8 (HHV8), causes KS. HHV8 DNA has been found in all variants of KS [10-13], and is found in c. $50 \%$ of blood samples from patients with the disease [14], but not from healthy blood donors. In asymptomatic HIV-infected patients, detection of HHV8 in peripheral blood mononuclear cells predicts the subsequent development of KS lesions [14, 15]. Although HHV8 is rarely detected in saliva or sputum of KS patients, detection of the virus in broncho-alveolar lavage fluid from AIDS patients is predictive of the presence of pulmonary KS [16].

HHV8 can be found in semen samples from HIVinfected gay men, but the reported frequency varies [17-19]. The virus has also been reported in semen samples from healthy donors by some $[18,19]$, but not all [17] groups. It is also present in many cases of multicentric Castleman's disease [20], a rare' syndrome consisting of angiofollicular hyperplasia, adenopathy and fever, which is statistically associated with KS. As these different reports illustrate, the extent to which HHV8 is present in the general population is still controversial.

Antibodies to a latent nuclear antigen can be detected by immunofluorescence in an HHV8 positive B-cell line [21-23]. Antibodies to a recombinant capsidrelated antigen have been detected by ELISA and Western blot [24]. Both are present in $80-90 \%$ of patients with Kaposi's sarcoma and in c. 30\% of homosexual men infected with HIV. However, antibodies to these antigens are seen in $<5 \%$ of patients with haemophilia or intravenous drug users, whether infected with HIV or not. Over $30 \%$ of HIV-negative African controls are antibody positive [22]. Antibodies to a set of undefined structural antigens have been found in $20 \%$ of blood donors in the USA [25]. Thus, the prevalence of HHV8 in the different HIV risk groups matches that expected for the postulated transmissible KS agent [7]. In Western countries it seems to be sexually transmitted and its epidemiology 
may resemble that of HSV-2 [23-25]. Geographic differences in HHV8 prevalence suggest that other modes of transmission may prevail in some African countries.

In AIDS patients, HHV8 has been consistently detected in the rare body cavity-related lymphoma [26] and occasionally in other B-cell lymphomas. Many of these lymphomas have also been positive for Epstein-Barr virus.

How HHV8 might contribute to the development of $\mathrm{KS}$ lesions is not yet known. One of the open reading frames codes for a protein that is a homologue of human D cyclins and it is possible that infected cells proliferate through a cyclin-dependent mechanism $[27,28]$. The HHV8 cyclin homologue can promote phosphorylation of the retinoblastoma protein and interacts with cdk6 [28]. A similar cyclin homologue is present in the herpesvirus saimiri genome, although it is not identical with the transforming genes, which are located at the opposite end of the genome. HHV8 also encodes an interleukin-6 homologue, which is expressed in infected B-cells, but not in KS lesions [29]. Other possibly transforming proteins encoded by HHV8 include: the chemokine homologues, MIP-1 and MIP-2; an interferon regulatory factor; and homologues of bcl-2, a G-protein coupled receptor and neural adhesion molecule [9,29]. Besides these, HHV8 has other genes with no obvious homology which may mediate as yet unknown transforming mechanisms $[9,28,29]$.

By in-situ PCR, HHV8 can be shown to infect both the spindle cells typical of advanced $\mathrm{KS}$ and the atypical flat endothelial cells lining vascular spaces of early KS lesions [30]. The virus establishes a latent infection consistent with a transforming role, and some genes that have the potential to interfere with the cell cycle or intracellular signalling (e.g., cyclin homologue, G-protein coupled receptor homologue) are expressed [27]. Thus, HHV8 may contribute to cell proliferation. Cell cultures established from KS lesions, including those capable of inducing the growth of 'KS-like' lesions in nude mice, often do not contain detectable HHV8 or lose it after a few passages [31].

Other factors besides HHV8 infection may contribute to the development of $\mathrm{KS}$. Immunosuppression is an important cofactor and probably allows HHV8 to replicate to high levels [14]. Experimental evidence suggests that the tat protein of HIV-1 may co-operate with a fibroblast growth factor to enhance $\mathrm{KS}$ cell proliferation [32]. The emergence of KS-like lesions in mice transgenic for HIV-1 tat has also been reported [33]. However, the role of tat in AIDS patients with $\mathrm{KS}$ has not been fully resolved. Hormonal co-factors have been proposed but their role in vivo awaits further corroboration [34].
While epidemiological findings, in particular the distribution of antibodies to HHV8 and its constant presence in $\mathrm{KS}$ lesions, support the role of this virus in the pathogenesis of $\mathrm{KS}$, its precise role in the development of the lesions remains to be elucidated.

H. D. L. BIRLEY and T. F. SCHULTZ Department of Medical Microbiology and Genitourinary Medicine, University of Liverpool, Duncan Building, Daulby Street, Liverpool L69 3GA

\section{References}

1. Kaposi M. Idiopathisches multiples Pigmentsarkom der Haut. Arch Dermatol Syphil 1872; 4: 742-749.

2. Roth WK, Brandstetter H, Stürzl M. Cellular and molecular features of HIV-associated Kaposi's sarcoma. AIDS 1992; 6: 895-913.

3. Stuerzl M, Brandstetter H, Zietz C. Growth factor and growth factor receptor expression in AIDS-related Kaposi's sarcoma in vivo suggests paracrine and autocrine mechanisms of tumour maintenance. $J$ Cell Biochem 1992; Suppl 16A: abstract CA112.

4. Salahuddin SZ, Nakamura S, Biberfeld $\mathrm{P}$ et al. Angiogenic properties of Kaposi's sarcoma-derived cells after long-term culture in vitro. Science 1988; 242: 430-433.

5. Rabkin CS, Bedi G, Musaba E et al. AIDS-related Kaposi's sarcoma is a clonal neoplasm. Clin Cancer Res 1995; 1: $257-260$.

6. Herndier BG, Werna A, Arnstein P et al. Characterization of a human Kaposi's sarcoma cell line that induces angiogenic tumors in animals. AIDS $1994 ; 8$ : $575-581$.

7. Beral V, Peterman TA, Berkelman RL, Jaffe HW. Kaposi's sarcoma among persons with AIDS: a sexually transmitted infection? Lancet 1990; 335: 123-128.

8. Chang Y, Cesarman E, Pessin MS et al. Identification of Herpesvirus-like DNA sequences in AIDS-associated Kaposi's sarcoma. Science 1994; 266: 1865-1869.

9. Russo JJ, Bohenzky RA, Chien M-C et al. Nucleotide sequence of the Kaposi's sarcoma-associated herpesvirus (HHV8). Proc Natl Acad Sci USA 1996; 93: 14862-14867.

10. Boshoff C, Whitby D, Hatziioannou T et al. Kaposi's-sarcomaassociated herpesvirus in HIV-negative Kaposi's sarcoma. Lancet 1995; 345: 1043-1044.

11. Moore PS, Chang Y. Detection of herpesvirus-like DNA sequences in Kaposi's sarcoma in patients with and without HIV infection. $N$ Engl J Med 1995; 332: 1181-1185.

12. Schalling M, Ekman M, Kaaya EE, Linde A, Biberfield P. A role for a new herpes virus (KSHV) in different forms of Kaposi's sarcoma. Nat Med 1995; 1: 707-708.

13. Chang Y, Ziegler J, Wabinga $\mathrm{H}$ et al. Kaposi's sarcomaassociated Herpesvirus and Kaposi's sarcoma in Africa. Arch Intern Med 1995; 156: 202-204.

14. Whitby D, Howard MR, Tenant-Flowers M et al. Detection of Kaposi sarcoma associated herpesvirus in peripheral blood of HIV-infected individuals and progression of Kaposi's sarcoma. Lancet 1995; 346: 799-802.

15. Moore PS, Kingsley LA, Holmberg SD et al. Kaposi's sarcoma-associated herpesvirus infection prior to onset of Kaposi's sarcoma. AIDS 1996; 10: 175-180.

16. Howard M, Brink N, Miller R, Tedder R. Association of human herpes virus with pulmonary Kaposi's sarcoma. Lancet 1995; 346: 712 .

17. Howard MR, Whitby D, Bahadur G et al. Detection of human herpesvirus 8 DNA in semen from HIV-infected individuals but not healthy semen donors. AIDS 1997 11: F15-F19.

18. Lin J-C, Lin S-C, Mar E-C et al. Is Kaposi's-sarcomaassociated herpesvirus detectable in semen of HIV-infected homosexual men? Lancet 1995; 346: 1601-1602.

19. Monini P, de Lellis L, Fabris M, Rigolin F, Cassai E. Kaposi's sarcoma-associated herpesvirus DNA sequences in prostate tissue and human semen. $N$ Engl $J$ Med 1996; 334: $1168-1172$. 
20. Soulier J, Grollet L, Oksenhendler E et al. Kaposi's sarcomaassociated herpesvirus-like DNA sequences in multicentric Castleman's disease. Blood 1995; 86: 1276-1280.

21. Gao S-J, Kingsley L, Hoover DR et al. Seroconversion to antibodies against Kaposi's sarcoma-associated herpesvirusrelated latent nuclear antigens before the development of Kaposi's sarcoma. $N$ Engl $J$ Med 1996; 335: 233-241.

22. Gao SJ, Kingsley L, Li M et al. KSHV antibodies among Americans, Italians, and Ugandans with and without Kaposi's sarcoma. Nat Med 1996; 2: 925-928.

23. Kedes DH, Operskalski E, Busch $M$ et al. The epidemiology of human herpesvirus 8 (Kaposi's sarcoma-associated herpesvirus): distribution of infection in KS risk groups and evidence for sexual transmission. Nat Med 1996; 2: 918-924.

24. Simpson GR, Schulz TF, Whitby D et al. Prevalence of Kaposi's sarcoma-associated herpesvirus infection measured by antibodies to recombinant capsid protein and latent immunofluorescence antigen. Lancet 1996; 348: 1133-1138.

25. Lennette ET, Blackbourn DJ, Levy JA. Antibodies to human herpesvirus type 8 in the general population and in Kaposi's sarcoma patients. Lancet 1996; 348: 858-861.

26. Cesarman E, Chang Y, Moore PS, Said JW, Knowles DM. Kaposi's sarcoma-associated herpesvirus-like DNA sequences in AIDS-related body-cavity-based lymphomas. $N$ Engl $J \mathrm{Med}$ 1995; 322: 1186-1191
27. Cesarman E, Nador RG, Bai $\mathrm{F}$ et al. Kaposi's sarcomaassociated herpesvirus contains $\mathrm{G}$ protein-coupled receptor and cyclin D homologs which are expressed in Kaposi's sarcoma and malignant lymphoma. $J$ Virol 1996; 70: 8218-8223.

28. Chang Y, Moore PS, Talbot SJ et al. Cyclin encoded by KS herpesvirus. Nature 1996; 382: 410.

29. Moore PS, Boshoff C, Weiss RA, Chang Y. Molecular mimicry of human cytokine and cytokine response pathway genes by KSHV Science 1996; 274: 1739-1744.

30. Boshoff C, Schulz TF, Kennedy MM et al. Kaposi's sarcomaassociated herpesvirus infects endothelial and spindle cells. Nat Med 1995; 1: 1274-1278.

31. Lebbé C, de Crémoux P, Rybojad M, Costa da Cunha C, Morel P, Calvo F. Kaposi's sarcoma and new herpesvirus. Lancet 1995; 345: 1180.

32. Ensoli B, Gendelman R, Markham P et al. Synergy between basic fibroblast growth factor and HIV-1 tat protein in induction of Kaposi's sarcoma. Nature 1994; 371: 674-680.

33. Vogel J, Hinrichs SH, Reynolds RK, Luciw PA, Jay G. The HIV tat gene induces dermal lesions resembling Kaposi's sarcoma in transgenic mice. Nature 1988; 335: 606-611.

34. Lunardi-Iskandar Y, Bryant JL, Zeman RA et al. Tumorigenesis and metastasis of neoplastic Kaposi's sarcoma cell line in immunodeficient mice blocked by a human pregnancy hormone. Nature 1995; 375: 64-68. 